\title{
Post-Depositional Biodegradation Processes of Pollutants on Glacier Surfaces
}

\author{
Francesca Pittino ${ }^{1}$ (i) , Roberto Ambrosini ${ }^{2}$, Roberto S. Azzoni ${ }^{2}$ (D), Guglielmina A. Diolaiuti ${ }^{2}$, \\ Sara Villa ${ }^{1}$, Isabella Gandolfi ${ }^{1}$ and Andrea Franzetti ${ }^{1, *}$ (ib \\ 1 Department of Earth and Environmental Sciences, University of Milano Bicocca, Piazza della Scienza, 1 \\ 20126 Milano, Italy; f.pittino@campus.unimib.it (F.P.); sara.villa@unimib.it (S.V.); \\ isabella.gandolfi@unimib.it (I.G.) \\ 2 Department of Environmental Science and Policy, University of Milan, via Celoria, 220133 Milano, Italy; \\ roberto.ambrosini@unimi.it (R.A.); robertosergio.azzoni@unimi.it (R.S.A.); \\ guglielmina.diolaiuti@unimi.it (G.A.D.) \\ * Correspondence: andrea.franzetti@unimib.it; Tel.: +39-02-64482927
}

Received: 14 July 2018; Accepted: 9 August 2018; Published: 11 August 2018

\begin{abstract}
Glaciers are important fresh-water reservoirs for our planet. Although they are often located at high elevations or in remote areas, glacial ecosystems are not pristine, as many pollutants can undergo long-range atmospheric transport and be deposited on glacier surface, where they can be stored for long periods of time, and then be released into the down-valley ecosystems. Understanding the dynamics of these pollutants in glaciers is therefore important for assessing their environmental fate. To this aim, it is important to study cryoconite holes, small ponds filled with water and with a layer of sediment, the cryoconite, at the bottom, which occur on the surface of most glaciers. Indeed, these environments are hotspots of biodiversity on glacier surface as they host metabolically active bacterial communities that include generalist taxa able to degrade pollutants. In this work, we aim to review the studies that have already investigated pollutant (e.g., chlorpyrifos and polychlorinated-biphenyls (PCBs)) degradation in cryoconite holes and other supraglacial environmental matrices. These studies have revealed that bacteria play a significant role in pollutant degradation in these habitats and can be positively selected in contaminated environments. We will also provide indication for future research in this field.
\end{abstract}

Keywords: cryoconite; POPs; microbiology; long-range transport; cryosphere; contaminants; bacteria

\section{Introduction}

For more than 40 years, we have known that inorganic and organic pollutants are present in cold remote areas, such as polar and mountain regions, far from their emission sources. Early studies were conducted in Arctic regions and reported high concentrations of radionuclides in layers corresponding to nuclear test periods [1] and the presence of chlorinated compounds in Arctic and Antarctic regions [2,3]. The organic contaminants in these remote areas are referred to as persistent organic pollutants (POPs), which consist of several groups of chemicals with similar structures and physical-chemical properties that are extensively used worldwide in agriculture (pesticides), industrial and health applications. Recent studies have revealed that alpine environments are affected by the presence of POPs [4-6]. These chemicals are ubiquitous, show long-range transport potential, and many of them are hydrophobic. In addition, they bio-accumulate in organisms via respiration, dermal contact, and through diet [7]. Some classes of contaminants comprised in the POPs are polychlorinated-biphenyls (PCBs), -dioxins (PCDDs), -furans (PCDFs), polybrominated-diphenyl ethers (PBDEs), -biphenyls (PBBs), perfluorinated compounds (PFCs) and other halogenated hydrocarbons, used as pesticides [8]. 
PCBs are one of the classes of compounds that have been studied in the context of pollutant biodegradation on glaciers [9]. They are toxic chemicals that the chemical treaty is trying to abolish by 2025 , because of their persistence and difficult degradation. Their use is very heterogeneous (from the industry to agriculture) [10]. PCB biodegradation can occur either through anaerobic reductive dechlorination (mostly in soil and sediment) or through aerobic oxidative degradation (preferably in water) and a wide range of different bacterial genera are able to perform these degradative pathways $[10,11]$. PCB degradation rate, measured in lab experiments, varies according to the number of the chlorine atoms, slowing down as the number of $\mathrm{Cl}^{-}$atoms increases. This is the reason why the range of the degradation rate varied from approximately $90 \%$ to approximately $20 \%$ [12].

Atmospheric medium- and long-range transport has been identified as a major source of semivolatile and persistent organic contaminants in polar and alpine ecosystems. Cold areas act as condensers [13], interfering with the atmospheric transport and global cycling of semi volatile organic compounds (SVOCs) [14-18], thus promoting the scavenging of these molecules from the atmosphere [19]. Indeed, PCB concentrations in snow increase with altitude, especially for more-volatile, less-chlorinated di- and tri-chlorobiphenyl congeners [4]. High altitude environments may also be more prone than polar ones to contamination by those compounds that are not suitable for long latitudinal transport because mountain ranges can be relatively close to source sites of contaminants [20].

A relevant fraction of the contaminants reaching cold areas is deposited on glaciers, where pollutants undergo post-depositional processes of partitioning among different environmental matrices (e.g., snow, ice, water, interstitial atmospheric gases and supraglacial sediments) and alteration processes. Post-depositional alteration consists of both physical-chemical processes, such as photodegradation, hydrolysis, revolatilization [21,22], and biological ones, particularly biodegradation [6]. The balance of these partition and alteration processes defines the amount of pollutants that can either enter the food-chain or be released into the environment by meltwater, which, in turn, can impact the downstream environments [23,24]. The current and foreseen increase of glacier retreat and melting will therefore likely lead to an increase of the release of pollutants from glaciers. Indeed, it has been already reported that high retreat episodes of glaciers correspond to high fluxes of pollutants in the melting water [25]. A recent model showed that the glacier melting due to global warming will lead to an earlier and more concentrated release of pollutants (e.g., PCBs, DDT, $\mathrm{PCDD} / \mathrm{Fs}$ ) stored in glacier bodies, than if the climate were stable [26].

Among post-depositional alteration processes that lead to the net reduction of the contaminant mass on the glacier, the biodegradation of organic molecules by microorganisms has been rather overlooked so far [6]. However, it is well known that microorganisms inhabit glaciers and have the metabolic abilities to degrade complex organic compounds even at low temperatures [27]. Among the glacial environments, supraglacial ones are the most biodiverse, and host rich bacterial communities [28]. In these environments, the cryoconite, a wind-borne fine debris deposited on glacier surfaces, represents a potential sink for organic and inorganic pollutants because of its high content of organic matter [29]. When heated by solar radiation, the cryoconite can promote ice melting and form small ponds filled by meltwater, called cryoconite holes, which are considered the most microbiologically active supraglacial habitats. Indeed, different studies report bacterial abundance in cryoconite in the order of $10^{8}-10^{9}$ cells $\cdot \mathrm{g}^{-1}[30,31]$, similar to these in other type of soils (e.g., agricultural soils, marsh or mountain soils) [32]. Cryoconite holes therefore represent ideal environments to investigate the processes that determine pollutant accumulation and degradation on glaciers [29].

In this work, we review the current literature about the accumulation of contaminants in the cryoconite and other supraglacial matrices and the microbiological processes affecting their fate, and we provide suggestions and direction for future research. 


\section{Accumulation of Pollutants and Microbiological Response in Cryoconite}

Cryoconite is a granular sediment found on glacier surfaces. Owing to its dark color, cryoconite absorbs solar radiation and promotes the formation of quasi-cylindrical holes, called cryoconite holes, through differential ablation rates compared to the surrounding ice [33]. Cryoconite is composed of both inorganic and organic material. The former is mainly composed by mineral fragments, often dominated by phyllosilicate, tectosilicate and quartz with differences due to the geological source of the debris [33]; the latter is composed of a wide variety of living and dead microscopic organisms, the products of their autotrophic activity, and allochthonous organic material of wind-borne particles [34]. Cryoconite in holes has higher concentration of organic matter and inorganic nutrients (nitrogen, phosphorus...) than the surrounding ice and supraglacial sediments $[35,36]$. This characteristic leads, on the one hand, to the incorporation of hydrophobic compounds such as POPs into the cryoconite organic matter [6] and, on the other hand, it promotes the presence of biodiverse and active microbial communities [37], which can biodegrade the contaminants.

In the last five years, some studies investigated the origin and the accumulation of pollutants in cryoconite and their post-depositional fate, including the biodegradation processes. Polycyclic Aromatic Hydrocarbons (PAHs) are among these pollutants. They are found in the environment as consequence of combustion or processing of hydrocarbon fuels. Their biodegradation can occur in different environments thanks to bacteria, fungi or algae and the efficiency depends on the number of benzene rings [38]. PAHs are known to be better biodegraded in water, but Kuppusamy and colleagues showed new consortia of bacteria able to perform PAH degradation in soil with good performances [39].

Li and colleagues identified 15 PAHs containing 3-7 rings in 61 cryoconite samples collected from seven glaciers on the Tibetan Plateau (TP) [40]. The average concentration of total PAHs in cryoconite samples was in the range of $6.67-3906.66 \mathrm{ng} \cdot \mathrm{g}^{-1}$ dry weight. The highest average total PAH concentration was found in the southeastern TP, followed by the northern TP. The central TP contained the lowest number of PAHs. Moreover, correlation analysis showed that total organic carbon (TOC) and grain size were only minor determinants of the accumulation of PAHs in cryoconite of the TP. Factor analysis and diagnostic ratios indicated that PAHs were produced mainly from the incomplete combustion of coal, fossil fuels and biomasses. The exhaust gas of locomotives also contributed to the accumulation of PAHs on glaciers. Toxicity Equivalent Quantity (TEQ) of cryoconite was calculated for all the glaciers and results showed that cryoconite had a low biological risk regarding PAHs in all the investigated glaciers, except for YL Snow Mountain, which is a touristic area where shuttle vehicles are widely used and five-seven ring PAHs accounted for more than half of total PAHs. Overall results showed that long-range atmospheric transport was the main source of PAHs deposited on glaciers.

Similarly, Dong and colleagues reported that the higher ratio of anthropogenic particles in the southern TP is likely caused by atmospheric pollutant transport from southern Asia, whereas cryoconite in the northern locations of the TP, containing higher dust and salt particle ratio, is influenced by the large deserts in central Asia [41]. Therefore, the transport and deposition of cryoconite is significant for understanding the regional atmospheric environment and circulation. A large amount of material such as biological particles, $\mathrm{NaCl}$, and mixed cation sulfate particles, was also found in the cryoconite, implying that, in addition to dust and black carbon, many types of light absorbing impurities combined could influence the glacier albedo change and enhance ice melting in the mountain glaciers of the TP.

The anthropogenic impact on cryoconite was also studied in the Alps and Arctic where high concentrations of radionuclides were found in two independent studies [42,43]. Both studies attributed the origin of these contaminants to long-range transport and anthropogenic activities. The extremely high concentration of metal and radioactive compounds was explained by the capability of extracellular substances excreted by microorganisms to bind these compounds and remove them from the meltwater. A recent study [44] investigated anthropogenic radionuclides in cryoconite from the Adishi glacier (Georgia) and found activity concentrations varying from $0.37 \pm 0.04 \mathrm{~Bq} \cdot \mathrm{Kg}^{-1}$ for ${ }^{238} \mathrm{Pu}\left({ }^{238} \mathrm{Pu}\right.$ activity concentrations in the first centimeter of soil in an undisturbed area in Korea was in the range of 
0.006-0.062 Bq. Kg ${ }^{-1}$ [45]) to a maximum of $4940 \pm 610$ for ${ }^{137} \mathrm{Cs}\left({ }^{137} \mathrm{Cs}\right.$ activity concentration detected after Fukushima nuclear accident at soil depth of $0.5-1 \mathrm{~cm}$ was $5610 \pm 40.8 \mathrm{~Bq} \cdot \mathrm{Kg}^{-1}$ [46]).

Interactions between radionuclides and bacteria can be very different: among them there are, noteworthy, biotransformation, bioprecipitation and also biosorption, depending on the characteristics of the radionuclides [47]. These compounds can be naturally present in the environment or due to human activity (e.g., nuclear weapons, uranium mining and milling, commercial fuel reprocessing) [48].

Due to the limited knowledge about glacial biology, how these high amounts of radionuclides and heavy metals affect biota and how these contaminants are transferred along food web remain open questions to be addressed in the future investigations.

To the best of our knowledge, only six studies characterized the microbial communities and their metabolisms associated to the contamination, besides addressing the presence of pollutants in cryoconite and other supraglacial environments

The metabolic potential of the culturable fraction of cryoconite bacteria toward pollutants was pioneeringly investigated by Margesin in 2002. In this study they estimated the abundance of bacteria able to grow on natural and anthropogenic recalcitrant substrates [49]. Results showed that cold-adapted bacteria were able to degrade carbohydrates (starch), fats (tributyrin), mineral oil hydrocarbons (diesel oil) and PAHs as sole carbon sources. (Table 1, Figure 1).

Table 1. Summary of the published studies addressing both the presence of pollutants and the microbial processes related to them in cryoconite and other supraglacial environmental matrices.

\begin{tabular}{cccc}
\hline Geographic Area & Contaminants & Matrices & Reference \\
\hline Italian Alps & Chlorpyrifos (CPF) & cryoconite & Ferrario et al., 2017 [41] \\
Antarctica & Synthetic oil & surface ice and sediments & Jarula et al., 2009 [38] \\
Greenland & 2,4-Dichlorophenoxyacetic Acid & surface ice & Stibal et al., 2012 [40] \\
Svalbard & Mercury & snow (above soil) & Larose et al., 2013 [35] \\
Austrian Alps & PCBs & cryoconite & Weiland-Bräuer et al., 2017 [39] \\
Greenland & PAHs, PCBs, mercury, lead & cryoconite & Hauptmann et al., 2017 [44] \\
\hline
\end{tabular}

Larose and colleagues [50] studied the impact of mercury, whose concentration is increasing in the Arctic food web, on snow microbial communities. Despite the investigated snowpack was not supraglacial, but consisted of seasonal snow accumulated above the soil, the study provides important insights into the response of cold adapted communities to inorganic contaminants.

Mercury can be subjected to long-range atmospheric transport and can persist in the air for at maximum one year: enough to reach also the most remote area of the planet [51]. $\mathrm{Hg}$ can be found in different forms: elemental $\mathrm{Hg}\left(\mathrm{Hg}^{0}(\mathrm{aq})\right)$ that is volatile but not reactive, mercuric species $(\mathrm{Hg}(\mathrm{II}))$ and organic mercury (e.g., methyl-mercury, that is bioaccumulative) [51]. Bacteria can play an important role reducing the soluble form $\mathrm{Hg}(\mathrm{II})$ to the precipitating $\mathrm{Hg}(0)$ and it has been demonstrated they can perform this reaction with better results at $\mathrm{Hg}$ (II) concentrations lower than $6 \mathrm{mg} / \mathrm{L}$ in water [52].

In the study by Larose et al. [50] both forms of mercury resulted to influence the structure of the snow microbial communities. Indeed, the microbiological analyses revealed the presence of mercury-resistant taxa in $\mathrm{Hg}$ contaminated snow and, at molecular level, the abundance of the merA gene, which confers resistance to the inorganic form of $\mathrm{Hg}$, was positively correlated with $\mathrm{Hg}$ concentration. merA codes for the mercuric reductase enzyme which catalyzes the reduction from the water soluble $\mathrm{Hg}(\mathrm{II})$ to the volatile $\mathrm{Hg}(0)$ form. The presence of this metabolic activity might also explain the observed reemission in the atmosphere of the $\mathrm{Hg}$ entrapped in the snow [53]. Further studies are needed regarding mercury in glacial ecosystems, especially regarding $\mathrm{Me}-\mathrm{Hg}$ that can be bioaccumulated along the trophic chain [51]. Indeed Larose et al., found a negative correlation between bioavailable $\mathrm{Hg}$ and $\mathrm{Me}-\mathrm{Hg}$ indicating a probable $\mathrm{Hg}$ biotic methylation [50]; in fact, bacteria can both cleave the bond or be responsible of methylation especially in anaerobic conditions [51,54]. $\mathrm{Hg}$ concentration in mountain firn core was found to be in the range of $2-35 \mathrm{ng} \cdot \mathrm{L}^{-1}$ [55], and in 
freshwater from uncontaminated sites was in the range of $1-20 \mathrm{ng} \cdot \mathrm{L}^{-1}[51]$, but a study by Moller and colleagues found in snow / brine concentrations of $70-80 \mathrm{ng} \cdot \mathrm{L}^{-1}$ [53].

The effect of organic molecule pollution was addressed in a work by Cappa and colleagues [56], who investigated the impact of a summer ski resort on the structure of bacterial communities on a glacier surface. Their findings revealed that the concentrations of PAHs and PCBs were significantly higher close to the ski resort than in areas impacted only by long-range transport. They also observed that the presence of pollutants can favor the selection of bacterial strains able to metabolize them. In another study, after that an unexpected synthetic oil spilling happened in Taylor Valley (Antarctica) because of a helicopter crash, biodegradation was detected preferentially in sediment rather than in water and fluid-filled bubbles of an ice core [57].

These first evidences that organic pollution can select specific degrading microbial populations, thus promoting the biodegradation of the same contaminants on glaciers, were further confirmed by subsequent studies, which reported the actual biological removal under field conditions and used molecular cultivation-independent methods to better characterize the microbial communities. For instance, the study by Weiland-Brauer and colleagues found high concentrations of eighteen different congeners of PCBs, 16 PAHs and 29 different organochlorine pesticides in the cryoconite of an Alpine glacier [9]. In this study, microcosms containing cryoconite were set up with the addition of PCBs to determine the bacteria responsible of PCB degradation. The results showed that different genera, among which the most abundant were Pseudomonas, Shigella, Polaromonas, Variovorax, Janthinobacterium, Subtercola, and Chitinophaga, were able to degrade PCBs. On a molecular basis, the ability to aerobically biodegrade PCBs was identified in the presence of the gene bphA coding for the enzyme biphenyl dioxygenase, which was found in both metagenomic DNA and in the genome of the bacterial isolates.

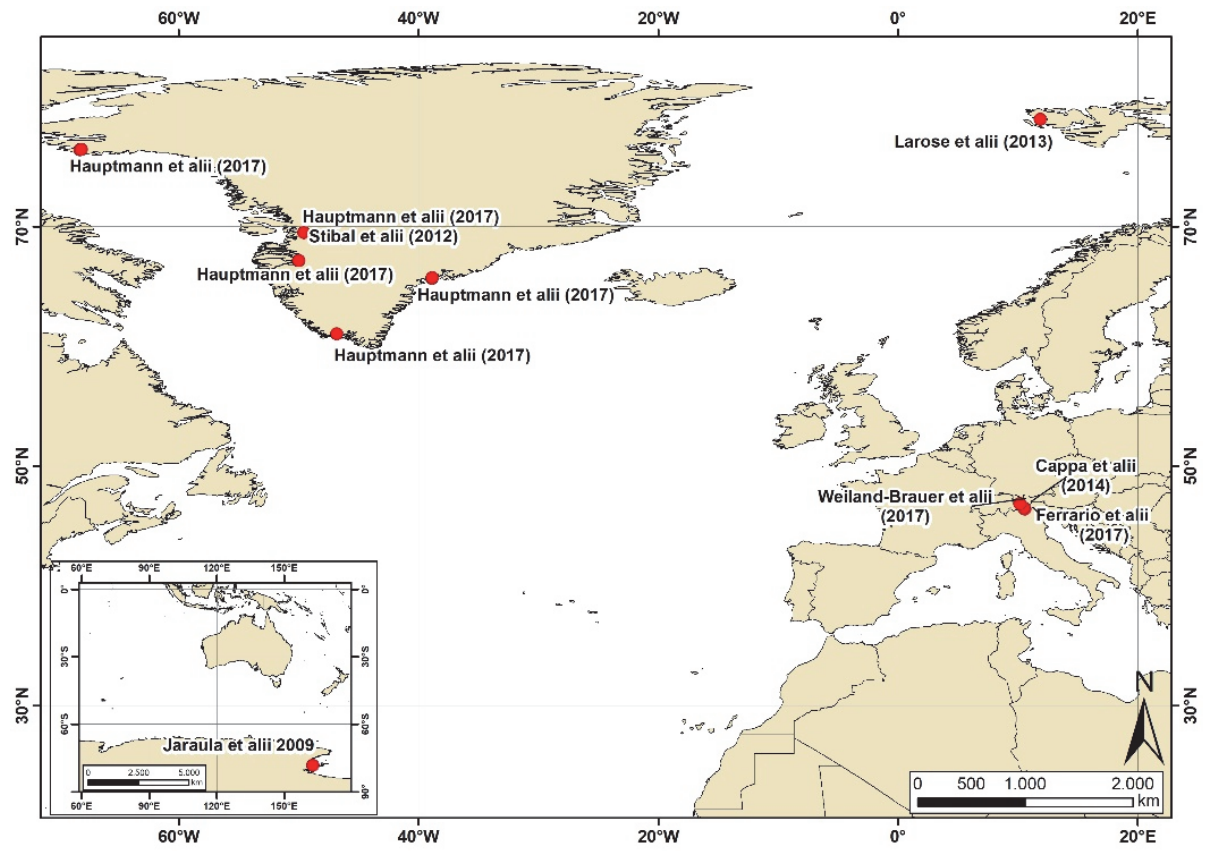

Figure 1. Geographic location of the studies addressing both the presence of pollutants and the microbial processes related to them in cryoconite and other supraglacial environmental matrices.

The microcosm approach was also used in two other studies with the aims of simulating glacier surface environments and estimating the biodegradation rates of pesticides [31,58]. In the first study, the ability of supraglacial bacteria to degrade the pesticide 2,4-dichlorophenoxyacetic acid (2,4-D) was investigated and, although no taxa related to known 2,4-D degraders were found, the authors succeeded in estimating the biodegradation rate in simulated field conditions. There are no data about 
the presence of this pesticide in/on glaciers, and not surprisingly, the rates of 2,4-D mineralization were lower than those observed in temperate environments. This work first demonstrated that anthropic contamination on glaciers can be attenuated by the local natural microbial community.

Ferrario and colleagues [16,31] detected high concentrations $\left(2-3 \mathrm{mg} \mathrm{kg}^{-1}\right)$ of the pesticide chlorpyrifos (CPF) in the cryoconite and meltwater of an Alpine glacier, while in agriculture and termiticidal initial soils (i.e., in the application area) its concentrations vary from 10 to $1000 \mathrm{mg}$ per $\mathrm{kg}$ of soil respectively [59]. The authors estimated, by in situ microcosms, that the rate of pollutant removal due to biodegradation was much higher than those of hydrolysis and photodegradation, leading to a CPF half-life in cryoconite ranging from 35 to 65 days (Figure 2). In other environments CPF half-life was reported to vary from 6 days (in aquatic aerobic conditions) to 128 days (in soil/slurry anaerobic conditions) [60], showing that in cryoconite the biodegradation rate is not different from others even if there are harsh conditions in this microhabitat. A whole shotgun metagenomics analysis of the bacteria occurring in the cryoconite of the same glacier allowed the genome reconstruction of a bacterial population that could be responsible of the pesticide biodegradation [31]. These putative CPF-degrading bacteria resulted to be photoheterotrophic Burkholderiales, thus strengthening previous findings on the metabolic versatility and the importance of Betaproteobacteria in the heterotrophic metabolisms of cold environments [37,61,62].

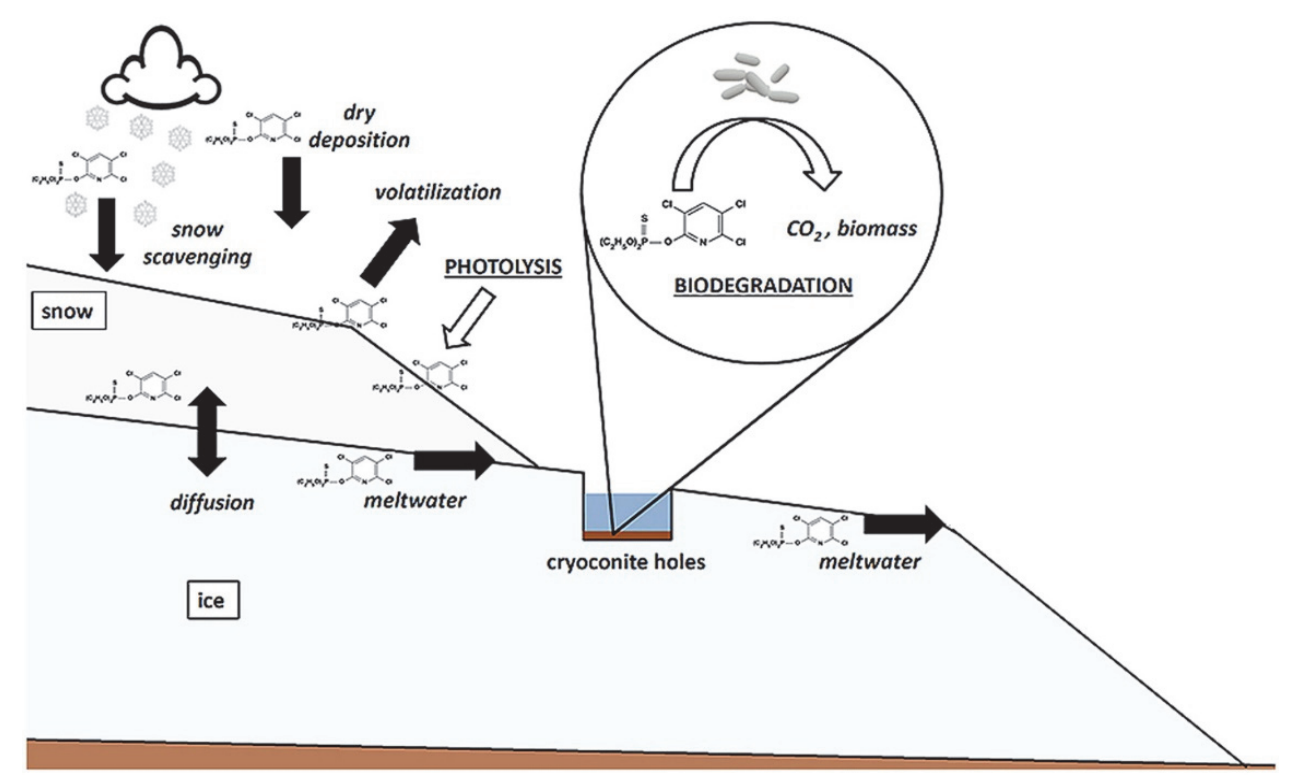

Figure 2. Processes affecting the fate of chlorpyrifos on the glacier surface. Biodegradation in cryoconite is highlighted. Reproduced with permission from Ferrario et al., 2017 [31].

A metagenomics approach was used also in a recent work addressing the metabolic potential of microbial communities in cryoconite collected on the Greenland ice sheet. Results disclosed the potential for resistance to and degradation of contaminants, including polychlorinated biphenyls (PCBs), polycyclic aromatic hydrocarbons (PAHs), and the heavy metals mercury and lead. The presence of genes for contaminant resistance and degradation was spatially variable but present in all samples across the ice sheet [63].

\section{Conclusions and Future Perspectives}

This short review of the studies that have addressed the biodegradation of pollutants on the glacier surface reveals how this field has been investigated only very recently, and that there is therefore a wide potential for future studies. New studies should investigate the biodegradation potential of glacier microbes for further pollutants that are known to occur on glaciers (e.g., terbuthylazine [16]). The review has also highlighted the importance of using microcosms to investigate degradation rates. 
A well-designed experimental setup of microcosms under different conditions (e.g., light and dark conditions, sterilized and non-sterilized cryoconite, etc., see [16] for an example) can indeed allow for the assessing of the relative contribution of different processes to pollutant degradation. We also stress the importance of carrying out microcosm studies in situ, whenever this is logistically feasible, in order to be as close as possible to natural conditions.

Another important feature emerging from this review is the potential of metagenomic studies to improve our understanding of the metabolic processes that allow glacier bacteria to degrade pollutants. Indeed, the identification of the microbial populations involved in these processes was critical in most studies. With the decrease of costs of sequencing and the availability of new bioinformatic tools that will ease these studies, we hope for further investigations of pollutant degradation on glaciers combining microcosms and metagenomics.

We also hope that further studies will fill the large geographical gaps in these investigations, for instance in South America. Finally, there is also a strong need for models of the environmental fate of pollutants in cold areas, which incorporate also biological processes, as they will be pivotal to properly forecast the future dynamics of contaminants released by glaciers in future warmer climatic conditions.

Acknowledgments: The authors acknowledge the valuable contribution of all former researchers and students involved in the studies of microbiological processes in glaciers. Among them, they particularly thank Claudio Smiraglia, Ilario Tagliaferri and Claudia Ferrario.

Conflicts of Interest: The authors declare no conflict of interest.

\section{References}

1. Jaworowski, Z.; Bilkiewicz, J.; Dobosz, E.; Wódkiewicz, L. Stable and radioactive pollutants in a Scandinavian glacier. Environ Pollut. 1975, 9, 305-315. [CrossRef]

2. Sladen, W.J.L.; Menzie, C.M.; Reichel, W.L. DDT Residues in Adelie Penguins and a Crabeater Seal from Antarctica. Nature 1966, 210, 670-673. [CrossRef] [PubMed]

3. Ottar, B. The transfer of airborne pollutants to the Arctic region. Atmos Environ. 1981, 15, 1439-1445. [CrossRef]

4. Blais, J.M.; Schindler, D.W.; Muir, D.C.G.; Kimpe, L.E.; Donald, D.B.; Rosenberg, B. Accumulation of persistent organochlorine compounds in mountains of western Canada. Nature 1998, 395, 585-588. [CrossRef]

5. Kang, J.H.; Choi, S.D.; Park, H.; Baek, S.Y.; Hong, S.; Chang, Y.S. Atmospheric deposition of persistent organic pollutants to the East Rongbuk Glacier in the Himalayas. Sci. Total Environ. 2009, 408, 57-63. [CrossRef] [PubMed]

6. Hodson, A.J. Understanding the dynamics of black carbon and associated contaminants in glacial systems. Wires Water 2014, 1, 141-149. [CrossRef]

7. Mangano, M.C.; Sarà, G.; Corsolini, S. Monitoring of persistent organic pollutants in the polar regions: Knowledge gaps \& gluts through evidence mapping. Chemosphere 2017, 172, 37-45. [PubMed]

8. Vanden Bilcke, C. The Stockholm Convention on Persistent Organic Pollutants. Rev. Eur. Commun. Int. Envtl. L. 2003, 11, 328-342. [CrossRef]

9. Weiland-Bräuer, N.; Fischer, M.A.; Schramm, K.W.; Schmitz, R.A. Polychlorinated Biphenyl (PCB)-Degrading Potential of Microbes Present in a Cryoconite of Jamtalferner Glacier. Front. Microbiol. 2017, 8. [CrossRef] [PubMed]

10. Borja, J.; Taleon, D.M.; Auresenia, J.; Gallardo, S. Polychlorinated biphenyls and their biodegradation. Process Biochem. 2005, 40, 1999-2013. [CrossRef]

11. Abraham, W.R.; Nogales, B.; Golyshin, P.N.; Pieper, D.H.; Timmis, K.N. Polychlorinated biphenyl-degrading microbial communities in soils and sediments. Curr. Opin. Microbiol. 2002, 5, 246-253. [CrossRef]

12. Cai, H.; Sheng, Q.Y.; He, Z.G.; Shi, W.L. Isolation, Identification and Characteristics of an Efficient PCBs-Degrading Strain. In Advances in Energy and Environmental Materials; Han, Y., Ed.; Springer: Singapore, 2017.

13. Calamari, D.; Bacci, E.; Focardi, S.; Gaggi, C.; Morosini, M.; Vighl, M. Role of Plant Biomass in the Global Environmental Partitioning of Chlorinated Hydrocarbons. Environ. Sci. Technol. 1991, 25, 1489-1495. [CrossRef] 
14. Carrera, G.; Fernández, P.; Vilanova, R.M.; Grimalt, J.O. Persistent organic pollutants in snow from European high mountain areas. Atmos. Environ. 2001, 35, 245-254. [CrossRef]

15. Villa, S.; Vighi, M.; Maggi, V.; Finizio, A.; Bolzacchini, E. Historical Trends of Organochlorine Pesticides in an Alpine Glacier. J. Atmos. Chem. 2003, 46, 295-311. [CrossRef]

16. Ferrario, C.; Finizio, A.; Villa, S. Legacy and emerging contaminants in meltwater of three Alpine glaciers. Sci. Total Environ. 2017, 574, 350-357. [CrossRef] [PubMed]

17. Arellano, L.; Fernández, P.; Fonts, R.; Rose, N.L.; Nickus, U.; Thies, H.; Stuchlík, E.; Camarero, L.; Catalan, J.; Grimalt, J.O. Increasing and decreasing trends of the atmospheric deposition of organochlorine compounds in European remote areas during the last decade. Atmos. Chem. Phys. 2015, 15, 6069-6085. [CrossRef]

18. Villa, S.; Vighi, M.; Finizio, A. Theoretical and experimental evidences of medium range atmospheric transport processes of polycyclic musk fragrances. Sci. Total Environ. 2014, 481, 27-34. [CrossRef] [PubMed]

19. Grannas, A.M.; Bogdal, C.; Hageman, K.J.; Halsall, C.; Harner, T.; Hung, H.; Kallenborn, R.; Klán, P.; Klánová, J.; Macdonald, R.W.; et al. The role of the global cryosphere in the fate of organic contaminants. Atmos. Chem. Phys. 2013, 13, 3271-3305. [CrossRef]

20. Kallenborn, R. Persistent organic pollutants (POPs) as environmental risk factors in remote high-altitude ecosystems. Ecotoxicol. Environ. Saf. 2006, 63, 100-107. [CrossRef] [PubMed]

21. Grannas, A.M.; Jones, A.E.; Dibb, J.; Ammann, M.; Anastasio, C.; Beine, H.J.; Bergin, M.; Bottenheim, J.; Boxe, C.S.; Carver, G.; et al. An overview of snow photochemistry: Evidence, mechanisms and impacts. Atmos. Chem. Phys. 2007, 7, 4329-4373. [CrossRef]

22. Herbert, B.M.J.; Villa, S.; Halsall, C.J. Chemical interactions with snow: Understanding the behavior and fate of semi-volatile organic compounds in snow. Ecotoxicol. Environ. Saf. 2006, 63, 3-16. [CrossRef] [PubMed]

23. Morselli, M.; Semplice, M.; Villa, S.; Di Guardo, A. Evaluating the temporal variability of concentrations of POPs in a glacier-fed stream food chain using a combined modeling approach. Sci. Total Environ. 2014, 493. [CrossRef] [PubMed]

24. Bizzotto, E.C.; Villa, S.; Vighi, M. POP bioaccumulation in macroinvertebrates of alpine freshwater systems. Environ. Pollut. 2009, 157, 3192-3198. [CrossRef] [PubMed]

25. Schmid, P.; Bogdal, C.; Blüthgen, N.; Anselmetti, F.S.; Zwyssig, A.; Hungerbühler, K. The Missing Piece: Sediment Records in Remote Mountain Lakes Confirm Glaciers Being Secondary Sources of Persistent Organic Pollutants. Environ. Sci. Technol. 2011, 45, 203-208. [CrossRef] [PubMed]

26. Bogdal, C.; Nikolic, D.; Luthi, M.P.; Schenker, U.; Scheringer, M.; Hungerbuhler, K. Release of Legacy Pollutants from Melting Glaciers: Model Evidence and Conceptual Understanding. Environ. Sci. Technol. 2010, 44, 4063-4069. [CrossRef] [PubMed]

27. Margesin, R. Alpine microorganisms: Useful tools for low-temperature bioremediation. J. Microbiol. 2007, 45, 281-285. [PubMed]

28. Boetius, A.; Anesio, A.M.; Deming, J.W.; Mikucki, J.A.; Rapp, J.Z. Microbial ecology of the cryosphere: Sea ice and glacial habitats. Nat. Rev. Microbiol. 2015, 13, 677-690. [CrossRef]

29. Cook, J.; Edwards, A.; Takeuchi, N.; Irvine-Fynn, T. Cryoconite: The dark biological secret of the cryosphere. Prog. Phys. Geogr. 2016, 40, 66-111. [CrossRef]

30. Stibal, M.; Schostag, M.; Cameron, K.A.; Hansen, L.H.; Chandler, D.M.; Wadham, J.L.; Jacobsen, C.S. Different bulk and active bacterial communities in cryoconite from the margin and interior of the Greenland ice sheet. Environ. Microbiol. Rep. 2014, 7, 293-300. [CrossRef] [PubMed]

31. Ferrario, C.; Pittino, F.; Tagliaferri, I.; Gandolfi, I.; Bestetti, G.; Azzoni, R.S.; Diolaiuti, G.; Franzetti, A.; Ambrosini, R.; Villa, S. Bacteria contribute to pesticide degradation in cryoconite holes in an Alpine glacier. Environ. Pollut. 2017, 230, 919-926. [CrossRef] [PubMed]

32. Henry, S.; Bru, D.; Stres, B.; Hallet, S.; Philippot, L. Quantitative detection of the nosZ gene, encoding nitrous oxide reductase, and comparison of the abundances of $16 \mathrm{~S}$ rRNA, narG, nirK, and nosZ genes in soils. Appl. Environ. Microb. 2006, 72, 5181-5189. [CrossRef] [PubMed]

33. Cook, J.; Edwards, A.; Takeuchi, N.; Irvine-Fynn, T. Cryoconite: The dark biological secret of the cryosphere. Prog. Phys. Geogr. 2015, 40, 66-111. [CrossRef]

34. Grzesiak, J.; Górniak, D.; Świątecki, A.; Aleksandrzak-Piekarczyk, T.; Szatraj, K.; Zdanowski, M.K. Microbial community development on the surface of Hans and Werenskiold Glaciers (Svalbard, Arctic): A comparison. Extremophiles 2015, 19, 885-897. [CrossRef] [PubMed] 
35. Franzetti, A.; Navarra, F.; Tagliaferri, I.; Gandolfi, I.; Bestetti, G.; Minora, U.; Azzoni, R.S.; Diolaiuti, G.; Smiraglia, C.; Ambrosini, R. Potential sources of bacteria colonizing the cryoconite of an Alpine glacier. PLoS ONE 2017, 12, e0174786. [CrossRef] [PubMed]

36. Bagshaw, E.A.; Tranter, M.; Fountain, A.G.; Welch, K.; Basagic, H.J.; Lyons, W.B. Do Cryoconite Holes have the Potential to be Significant Sources of C, N, and P to Downstream Depauperate Ecosystems of Taylor Valley, Antarctica? Arct. Antarct. Alp. Res. 2013, 45, 440-454. [CrossRef]

37. Franzetti, A.; Tagliaferri, I.; Gandolfi, I.; Bestetti, G.; Minora, U.; Azzoni, R.S.; Diolaiuti, G.; Smiraglia, C.; Ambrosini, R. Light-dependent microbial metabolisms driving carbon fluxes on glacier surfaces. ISME J. 2016, 10, 2984-2988. [CrossRef] [PubMed]

38. Haritash, A.K.; Kaushik, C.P. Biodegradation aspects of Polycyclic Aromatic Hydrocarbons (PAHs): A review. J. Hazard. Mater. 2009, 169, 1-15. [CrossRef] [PubMed]

39. Kuppusamy, S.; Thavamani, P.; Megharaj, M.; Naidu, R. Biodegradation of polycyclic aromatic hydrocarbons (PAHs) by novel bacterial consortia tolerant to diverse physical settings - Assessments in liquid and slurry-phase systems. Int. Biodeter. Biodegr. 2016, 108, 149-157. [CrossRef]

40. Li, Q.; Kang, S.; Wang, N.; Li, Y.; Li, X.; Dong, Z.; Chen, P. Composition and sources of polycyclic aromatic hydrocarbons in cryoconites of the Tibetan Plateau glaciers. Sci. Total Environ. 2017, 574, 991-999. [CrossRef] [PubMed]

41. Dong, Z.; Qin, D.; Kang, S.; Liu, Y.; Li, Y.; Huang, J.; Qin, X. Individual particles of cryoconite deposited on the mountain glaciers of the Tibetan Plateau: Insights into chemical composition and sources. Atmos. Environ. 2016, 138, 114-124. [CrossRef]

42. Łokas, E.; Zaborska, A.; Kolicka, M.; Różycki, M.; Zawierucha, K. Accumulation of atmospheric radionuclides and heavy metals in cryoconite holes on an Arctic glacier. Chemosphere 2016, 160, 162-172. [CrossRef] [PubMed]

43. Baccolo, G.; Di Mauro, B.; Massabò, D.; Clemenza, M.; Nastasi, M.; Delmonte, B.; Prata, M.; Prati, P.; Previtali, E.; Maggi, V. Cryoconite as a temporary sink for anthropogenic species stored in glaciers. Sci. Rep. 2017, 7, 9623. [CrossRef] [PubMed]

44. Łokas, E.; Zawierucha, K.; Cwanek, A.; Szufa, K.; Gaca, P.; Mietelski, J.W.; Tomankiewicz, E. The sources of high airborne radioactivity in cryoconite holes from the Caucasus (Georgia). Sci. Rep. 2018, 8, 10802. [CrossRef] [PubMed]

45. Kim, C.S.; Lee, M.H.; Kim, C.K.; Kim, K.H. ${ }^{90} \mathrm{Sr},{ }^{137} \mathrm{Cs},{ }^{239+240} \mathrm{Pu}$ and ${ }^{238} \mathrm{Pu}$ Concentrations in Surface Soils of Korea C. J. Environ. Radioact. 1998, 40, 75-88. [CrossRef]

46. Kato, H.; Onda, Y.; Teramage, M. Depth distribution of ${ }^{137} \mathrm{Cs},{ }^{134} \mathrm{Cs}$, and ${ }^{131} \mathrm{I}$ in soil profile after Fukushima Dai-ichi Nuclear Power Plant Accident. J. Environ. Radioact. 2012, 111, 59-64. [CrossRef] [PubMed]

47. Shukla, A.; Parmar, P.; Saraf, M. Radiation, radionuclides and bacteria: An in-perspective review. J. Environ. Radioact. 2017, 180, 27-35. [CrossRef] [PubMed]

48. Hu, Q.H.; Weng, J.Q.; Wang, J.S. Sources of anthropogenic radionuclides in the environment: A review. J. Environ. Radioact. 2010, 101, 426-437. [CrossRef] [PubMed]

49. Margesin, R.; Zacke, G.; Schinner, F. Characterization of heterotrophic microorganisms in alpine glacier cryoconite. Arct. Antarct. Alp. Res. 2002, 34, 88-93. [CrossRef]

50. Larose, C.; Prestat, E.; Cecillon, S.; Berger, S.; Malandain, C.; Lyon, D.; Ferrari, C.; Schneider, D.; Dommergue, A.; Vogel, T.M. Interactions between Snow Chemistry, Mercury Inputs and Microbial Population Dynamics in an Arctic Snowpack. PLoS ONE 2013, 8, e79972. [CrossRef] [PubMed]

51. Morel, F.M.M.; Kraepiel, A.M.L.; Amyot, M. The Chemical Cycle and Bioaccumulation of Mercury. Annu. Rev. Ecol. Syst. 1998, 29, 543-566. [CrossRef]

52. Von Canstein, H.; Li, Y.; Leonhäuser, J.; Haase, E.; Felske, A.; Deckwer, W.D.; Wagner-Döbler, I. Spatially oscillating activity and microbial succession of mercury-reducing biofilms in a technical-scale bioremediation system. Appl. Environ. Microb. 2002, 68, 1938-1946. [CrossRef]

53. Møller, A.K.; Barkay, T.; Al-Soud, W.A.; Sørensen, S.J.; Skov, H.; Kroer, N. Diversity and characterization of mercury-resistant bacteria in snow, freshwater and sea-ice brine from the High Arctic. FEMS Microbiol. Ecol. 2011, 75, 390-401. [CrossRef] [PubMed]

54. Colombo, M.J.; Ha, J.; Reinfelder, J.R.; Barkay, T.; Yee, N. Anaerobic oxidation of $\mathrm{Hg}(0)$ and methylmercury formation by Desulfovibrio desulfuricans ND132. Geochim. Cosmochim. Acta. 2013, 112, 166-177. [CrossRef] 
55. Wang, X.P.; Yao, T.D.; Wang, P.L.; Yang, W.; Tian, L.D. The recent deposition of persistent organic pollutants and mercury to the Dasuopu glacier, Mt. Xixiabangma, central Himalayas. Sci. Total Environ. 2008, 394, 134-143. [CrossRef] [PubMed]

56. Cappa, F.; Suciu, N.; Trevisan, M.; Ferrari, S.; Puglisi, E.; Cocconcelli, P.S. Bacterial diversity in a contaminated Alpine glacier as determined by culture-based and molecular approaches. Sci. Total Environ. 2014, 497-498, 50-59. [CrossRef] [PubMed]

57. Jaraula, C.M.B.; Kenig, F.; Doran, P.T.; Priscu, J.C.; Welch, K.A. Composition and Biodegradation of a Synthetic Oil Spilled on the Perennial Ice Cover of Lake Fryxell, Antarctica. Environ. Sci. Technol. 2009, 43, 2708-2713. [CrossRef] [PubMed]

58. Stibal, M.; Bælum, J.; Holben, W.E.; Sørensen, S.R.; Jensen, A.; Jacobsen, C.S. Microbial degradation of 2,4-dichlorophenoxyacetic acid on the Greenland ice sheet. Appl. Environ. Microb. 2012, 78, 5070-5076. [CrossRef] [PubMed]

59. Murray, R.T.; Von Stein, C.; Kennedy, I.R.; Sanchez-Bayo, F. Stability of chlorpyrifos for termiticidal control in six Australian soils. J. Agric. Food Chem. 2001, 49, 2844-2847. [CrossRef] [PubMed]

60. Tiwari, M.K.; Guha, S. Kinetics of biotransformation of chlorpyrifos in aqueous and soil slurry environments. Water Res. 2014, 51, 73-85. [CrossRef] [PubMed]

61. Darcy, J.L.; Lynch, R.C.; King, A.J.; Robeson, M.S.; Schmidt, S.K. Global Distribution of Polaromonas Phylotypes-Evidence for a Highly Successful Dispersal Capacity. PLoS ONE 2011, 6, e23742. [CrossRef] [PubMed]

62. Caliz, J.; Casamayor, E.O. Environmental controls and composition of anoxygenic photoheterotrophs in ultraoligotrophic high-altitude lakes (Central Pyrenees). Env. Microbiol. Rep. 2014, 6, 145-151. [CrossRef] [PubMed]

63. Hauptmann, A.L.; Sicheritz-Pontén, T.; Cameron, K.A.; Bælum, J.; Plichta, D.R.; Dalgaard, M.; Stibal, M. Contamination of the Arctic reflected in microbial metagenomes from the Greenland ice sheet. Environ. Res. Lett. 2017, 12, 074019. [CrossRef] 